\title{
С.Д. Новиченко
}

\section{ХАРАКТЕРИСТИКА ВІЛЬНОРАДИКАЛЬНОГО УШКОДЖЕННЯ ТА СТАНУ АНТИОКСИДАНТНОГО ЗАХИСТУ У ХВОРИХ НА ХРОНІЧНУ ХВОРОБУ НИРОК ІЗ НАЯВНІСТЮ АРТЕРІАЛЬНОЇ ГІПЕРТЕНЗІЇ}

Вищий державний навчальний заклад України «Буковинський державний медичний університет», м. Чернівці

Резюме. У роботі вивчено вільнорадикальне окиснення ліпідів і білків та стан антиоксидантного захисту у хворих на хронічну хворобу нирок із наявністю артеріальної гіпертензії. Проведено порівняльну характеристику досліджуваних показників при різних захворюваннях нирок, що супроводжуються виникненням артеріальної гіпертензії. Виявлено найбільш виражене зрушення окисно-відновних процесів у пацієнтів із діабети-

Вступ. Вільнорадикальне окиснення (ВРО) ліпідів та білків є однією з форм тканинного дихання. Цей процес властивий нормальним тканинам і відбувається, як правило, при побудові ліпідних мембранних структур, їх оновленні, у ході біосинтезу ряду гормонів $[1,2,4,10]$. Проте вільнорадикальне окиснення може активізуватися в несприятливій екологічній ситуації, за дії алкоголю, тютюнового диму, а також при багатьох захворюваннях внутрішніх органів, зокрема при хронічній хворобі нирок (ХХН) $[3,5,6,8]$. Надмірна активація процесів ВРОЛ веде до порушення структури мембран, ліпідного обміну, здійснює токсичний вплив на тканини, сприяє посиленню лізису, окисненню сульфгідрильних груп білків і призводить до розвитку структурних змін при захворюваннях нирок $[3,6,7]$. Регуляція стаціонарної концентрації пероксидів ліпідів у біологічних мембранах здійснюється внаслідок збалансованої взаємодії реакцій утворення цих продуктів - реакцій оксидації, а також механізмів контролю, які ведуть до пригнічення їх утворення, - реакцій антиоксидації $[5,7,9]$.

Дані літератури вказують на велику роль процесів оксидації у пошкодженні ниркових структур, особливо при прогресуванні ХХН, що зумовлено появою артеріальної гіпертензії (АГ) $[3,5,9]$. Однак досі не з'ясовано значущості пошкоджуючої дії ВРО у хворих з різними нозологічними формами ХХН з наявністю АГ.

Мета дослідження. Провести порівняльну характеристику стану вільнорадикального окиснення ліпідів, білків та антиоксидантного захисту у хворих на хронічну хворобу нирок I стадії 3 різними нозологічними формами, 3 наявністю артеріальної гіпертензії .

Матеріал і методи. Обстежено 77 хворих на XXН I стадії 3 наявністю АГ II ступеня та 20 практично здорових осіб. Контрольну групу склали 25 пацієнтів із гіпертонічною хворобою II ступеня без ураження нирок. Всі обстежені були віком від 37 до 70 років. Пацієнтів було розподілено на групи: I група - із хронічним пієлонефритом (26 осіб); II група - із хронічним гломеруло(с) С.Д. Новиченко, 2016

108 чною нефропатією та гломерулонефритом порівняно 3 іншими нозологічними формами хронічної хвороби нирок.

Ключові слова: хронічна хвороба нирок, вільнорадикальне окиснення ліпідів та білків, пієлонефрит, гломерулонефрит, діабетична нефропатія, гіпертонічна хвороба.

нефритом (25 осіб); III група - із діабетичною нефропатією (ДН) IV стадії (26 осіб). Крім загальноприйнятих та нефрологічних методів обстеження, усім пацієнтам проводилося дослідження системи ВРО. Стан перекисного окиснення ліпідів (ПОЛ) оцінювали за рівнем вторинних продуктів вільнорадикального окиснення - малонового альдегіду (МА). Інтенсивність окиснювальної модифікації білків у сироватці крові (альдегід- і кетондинітрофенілгідразони нейтрального та основного характеру) визначали за методом О.Ю. Дубініної в модифікації І.Ф. Мещишена (1998). Рівень МА досліджували за Ю.А. Владимировим, А.І. Арчаковим. Визначення активності глутатіонпероксидази (ГПх) та глутатіон-S-трансферази (ГsТ)проводили за методом I.Ф. Мещишена. Активність зазначених ферментів розраховували на 1 г гемоглобіну (Нв). Вміст у крові глутатіону відновленого (Гл-SH) визначали титраційним методом за О.В. Травіною в модифікації І.Ф. Мещишена, I.В. Петрової.

Отримані дані оброблені статистично з використанням критеріїв Стьюдента. Усі показники представлені у вигляді середніх значень з їх середніми похибками $(\mathrm{M} \pm \mathrm{m})$. Достовірними вважали різниці при $\mathrm{p}<0,05$. Проведення дослідження виконане у відповідності з етичними нормами Гельсінської декларації перегляду 2008 року.

Результати дослідження та їх обговорення. Результати наших досліджень показали, що $\epsilon$ суттєва різниця в перебігу пероксидних процесів у крові хворих на ХХН I стадії з наявністю АГ II ступеня залежно від нозології захворювання нирок, що подано в таблиці 1.

Згідно 3 даними, наведеними в таблиці $1, \mathrm{y}$ сироватці крові обстежених із наявністю пієлонефриту відмічалося достовірне зростання вмісту альдегід- та кетондинітрофенілгідразонів нейтрального та основного характеру порівняно 3 нормою ( $<0,05)$, але вірогідними у порівнянні з групою контролю були тільки показники альдегідта кетондинітрофенілгідразонів нейтрального характеру $(\mathrm{p}<0,05)$. Найбільше підвищення досліджуваних показників відмічалося у пацієнтів із 


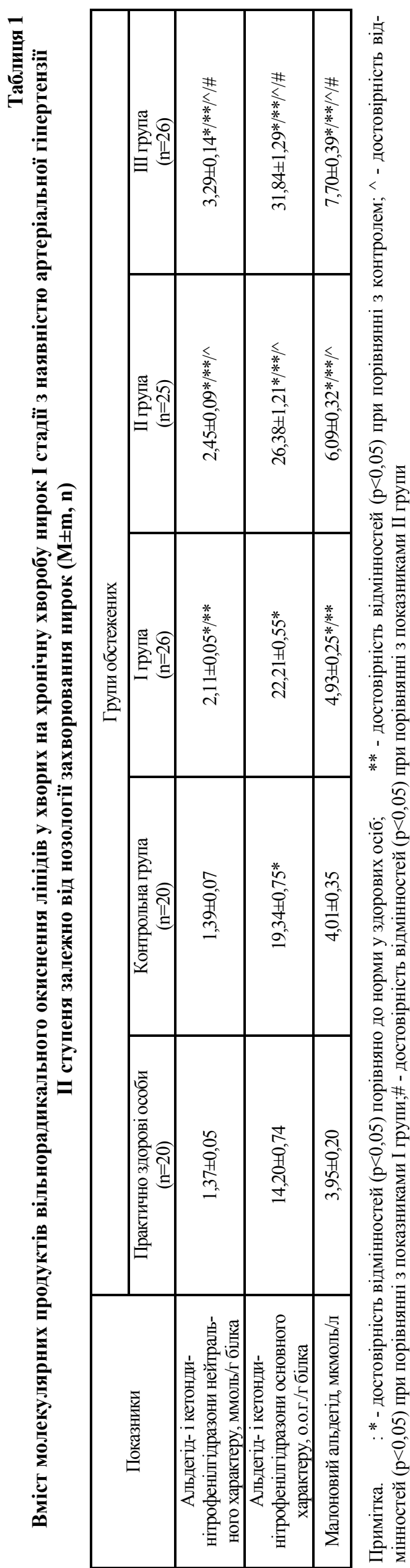

наявністю ДН (p<0,05), що було вірогідним як до групи здорових, так і до всіх інших груп дослідження. Слід відзначити, що відповідним чином відреагували показники альдегід- та кетондинітрофенілгідразонів нейтрального (у 2,4 раза порівняно 3 нормою) та основного характеру (у 2,2 раза). У пацієнтів з наявністю гломерулонефриту збільшення рівня альдегід- та кетондинітрофенілгідразонів нейтрального та основного характеру порівняно з нормою відбулося відповідно в 1,9 та 1,8 раза $(\mathrm{p}<0,05)$. Дані показники у хворих на гломерулонефрит були вірогідно підвищеними також у порівнянні з групою контролю (p<0,05 ).

Вміст МА у групах дослідження коливався також відповідно нефрологічної нозології та меншою мірою залежав від наявності АГ (табл. 1).

Так, рівень МА був найвищим у хворих на XXH I ст. $з$ наявністю АГ II ст., що мали ДН (III група) порівняно з відповідними даними практично здорових $(\mathrm{p}<0,001)$, групи контролю $(\mathrm{p}<0,05)$, I та II груп відповідно $(\mathrm{p}<0,05)$. У хворих II групи показники також вірогідно відрізнялися від норми $(\mathrm{p}<0,05)$, даних групи контролю $(\mathrm{p}<0,05)$ та I групи $(\mathrm{p}<0,05)$. Показники МА I групи були вірогідно підвищені порівняно з нормою та групою контролю відповідно $(\mathrm{p}<0,05)$.

Отримані дані свідчать про те, що інтенсивність процесів ВРО у хворих на ХХН I стадії із АГ II ст. певною мірою залежать від наявності типу ураження нирок. Так, у крові хворих на гіпертонічну хворобу без ураження нирок (контрольна група) вірогідні зміни показників ВРО відбулися тільки з боку альдегід- та кетондинітрофенілгідразонів основного характеру $(\mathrm{p}<0,05)$. Найінтенсивніші зміни відбулися з боку показників ВРО хворих на ХХН I ст.з наявністю АГ, що мали гломерулонефрит та ДН.

Аналіз результатів дослідження системи глутатіону (табл .2) показав, що вміст глутатіону відновленого (Гл-SH) у крові зменшувався в усіх групах пацієнтів відносно показників практично здорових осіб відповідно $(\mathrm{p}<0,05)$, причому за відсутності захворювань нирок (група контролю) його рівень був також вірогідно зниженим $(\mathrm{p}<0,05)$. Рівень Гл-SH найбільше знижувався в пацієнтів III групи - в 1,5 раза $(\mathrm{p}<0,05)$, але у хворих II групи вміст Гл-SH також був значно зниженим - в 1,2 раза $(\mathrm{p}<0,05)$ порівняно 3 нормою. У пацієнтів I групи показники Гл-SH були найменш зниженими, але вірогідно відрізнялися від норми $(\mathrm{p}<0,05)$. Це можна пояснити найменш істотною розбалансованістю оксидантно-протиоксидантного гомеостазу у хворих на пієлонефрит. Активність ГПх вірогідно знижувалася у всіх групах хворих $(\mathrm{p}<0,05)$ та незначно відрізнялася відносно норми у пацієнтів групи контролю $(\mathrm{p}>0,05)$. Найбільш вираженим зниження ГПх відзна- 


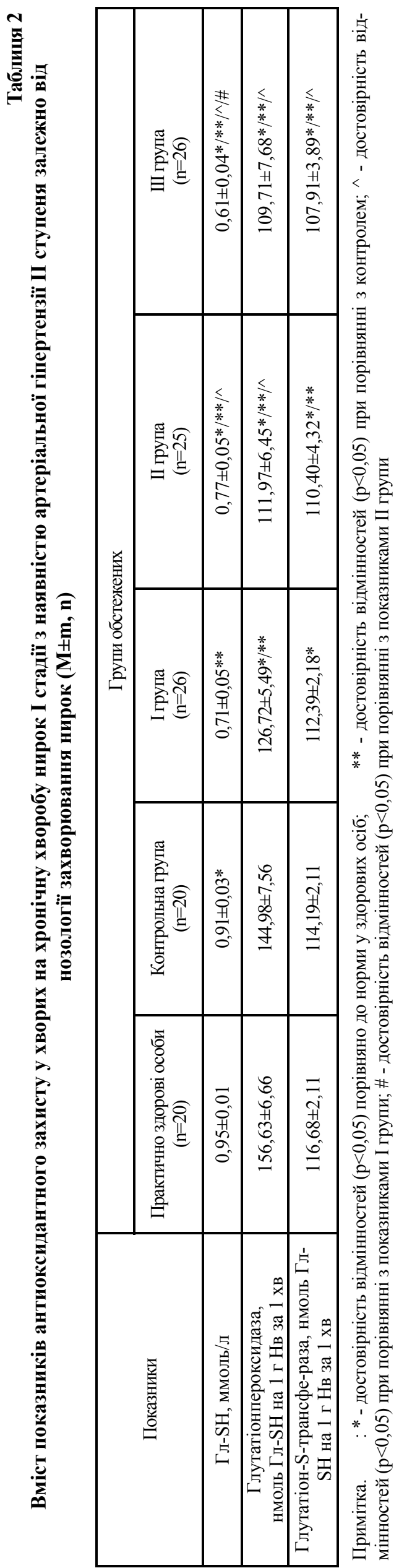

чалося у пацієнтів з гломерулонефритом та ДН та мало достовірну різницю 3 вмістом даного показника 3 відповідними даними I групи (р<0,05) (табл. 2).

Активність глутатіон-S-трансферази (ГsT) знижувалися подібним чином. Так, найнижчими дані показники були також у хворих на XXН I ст.з АГ з наявністю гломерулонефриту та ДН, що було вірогідним порівняно 3 нормою $(\mathrm{p}<0,05)$, групою контролю $(\mathrm{p}<0,05)$, а також 3 I групою пацієнтів $(\mathrm{p}<0,05)$.

Отже, XXН $з$ наявністю АГ ІІ ст. супроводжується значним підвищенням вмісту в крові альдегід- і кетондинітрофенілгідразонів, особливо нейтрального характеру, а також кінцевого продукту ВРОЛ - малонового альдегіду, а також достовірним зниженням показників системи антиоксидантного захисту, що найбільше проявилося у хворих на гломерулонефрит та ДН.

\section{Висновки}

1. Суттєвим фактором розвитку та прогресування хронічної хвороби нирок у хворих з артеріальною гіпертензією II ст. є підвищення інтенсивності процесів вільнорадикального окиснення ліпідів та окиснювальної модифікації білків сироватки крові (переважно за рахунок альдегід- і кетондинітрофенілгідразонів нейтрального характеру).

2. Декомпенсація механізмів адаптації у хворих на хронічну хворобу нирок з наявністю артеріальної гіпертензії II ст. відбувається внаслідок істотного зменшення рівнів показників антиоксидантного захисту.

3. Найбільш істотні зміни оксидантнопротиоксидантного дисбалансу відбулися у хворих на хронічну хворобу нирок I ст. 3 артеріальною гіпертензією II ст. з наявністю гломерулонефриту та діабетичної нефропатії, що меншою мірою залежало від наявності АГ.

Перспективи подальших досліджень. У подальшому вивчатимуться зміни показників перекисного окиснення ліпідів в сечі хворих на хронічну хворобу нирок з різними нозологічними формами.

\section{Література}

1. Голод Е.А. Роль кислородных радикалов в нарушениях метаболизма в почках больных острым и хроническим пиелонефритом / Е.А. Голод, В.И. Кирпатовский // Патолог. физиол. и эксперим. терапия. - 2006. № 1. - С. 23-27.

2. Дубинина Е.Е. Окислительная модификация протеинов, ее роль при патологических состояниях / Е.Е. Дубинина, А.В. Пустыгина// Укр.біохім. ж. 2008. - Т. 80, № 6. - С. 5-18.

3. Іванов Д.Д. Хронічна хвороба нирок / Д.Д. Іванов // Внутр. мед. - 2007. - № 2. - С. 23-27.

4. Состояние системы глутатиона и перекисного окисления липидов в тканях печени и почек крыс при остром отравлении циклофосфаном / В.А. Кашуро, А.И. Карпищенко, С.И. Глушков [и др.] // Нефрология. - 2006. - № 2. - С. 81-85.

5. Мазо Е.Б. Хронический пиелонефрит: особенности иммунопатогенеза и их клинико-диагностическая значимость / Е.Б. Мазо, Л.И. Винницкий, В.А. Литвинов // Терапевт. архив. - 2007. - Т. 79, № 1. - С. 85-89. 
6. Паскалев Д. Клинико-лабораторные признаки, способствующие обьектизации диагностики обострения хронического пиелонефрита / Д. Паскалев // Нефрология. $-2007 .-$ Т. 11, № 1. - С. 83-86.

7. Рудиченко Е.В. Нарушения липидного обмена системы перекисного окисления у больных с хроническим пиелонефритом / Е.В. Рудиченко, М.В. Антонюк, Т.А. Гвозденко // Клин. мед. - 2006. - Т. 84, № 5. C. 54-58.

8. Fonfstock R. The interaction of urinary tract infection and renal insufficiency / R. Fonfstock, U.Ott, K.G. Naber //
Int. J. Antimicrob. Agents. - 2006. - Vol. 28, Suppl. 1. S. 72-77.

9. Levey A.S. National Kidney Foundation practice guidelines for chronic kidney disease: evaluation, classification, and stratification / A.S. Levey, J. Coresh, E. Balk // Ann. Intern. Med. - 2008. - № 139 (2). - P. 137-147.

10. Niki E. Lipid peroxidation: physiological levels and dual biological effects / E. Niki // Free Radical Biology\&Medicine. - 2009. - Vol. 47, № 5. - P. 469-484.

\section{ХАРАКТЕРИСТИКА СВОБОДНОРАДИКАЛЬНОГО ПОРАЖЕНИЯ И СОСТОЯНИЯ АНТИОКСИДАНТНОЙ ЗАЩИТЫ У БОЛЬНЫХ ХРОНИЧЕСКОЙ БОЛЕЗНЬЮ ПОЧЕК С НАЛИЧИЕМ АРТЕРИАЛЬНОЙ ГИПЕРТЕНЗИИ}

\section{С.Д. Новиченко}

Резюме. В работе изучено свободнорадикальное окисление липидов и белков, а также состояние антиоксидантной защиты у больных хронической болезнью почек с наличием артериальной гипертензии. Проведено сравнительную характеристику данных показателей при различных заболеваниях почек, которые сопровождаются возникновением артериальной гипертензии. Выявлено наиболее выраженное нарушение окислительно-восстановительных процессов у пациентов с диабетической нефропатией и гломерулонефритом в сравнении с другими нозологическими формами хронической болезни почек.

Ключевые слова: хроническое заболевание почек, свободнорадикальное окисление липидов и белков, пиелонефрит, гломерулонефрит, диабетическая нефропатия, гипертоническая болезнь.

\section{CHARACTERISTICS OF FREE RADICAL DAMAGE AND ANTIOXIDANT PROTECTION IN PATIENTS WITH CHRONIC KIDNEY DISEASE COMBINED WITH HYPERTENSION}

\section{S.D. Novychenko}

Abstract. We have established free radical oxidation of lipids and proteins and antioxidant status in patients with chronic kidney disease combined with hypertension. We conducted comparative characteristics of indicators in various diseases of the kidneys, accompanied by the occurrence of hypertension. It was estimated, that $t$ the patients with diabetic nephropathy and glomerulonephritis had the most intensive changes in oxidation-reduction processes compared to other nosological forms of chronic kidney disease.

Key words: chronic kidney disease, free radical oxidation of lipids and proteins, pyelonephritis, glomerulonephritis, diabetic nephropathy, hypertension.

Higher State Educational Institution of Ukraine «Bukovinian State Medical University» (Chernivtsi)

Рецензент - проф. О.І. Волошин

Buk. Med. Herald. - 2016. - Vol. 20, № 2 (78). - P. 108-111

Надійшла до редакції 11.04.2016 року

(ㄷ С.Д. Новиченко, 2016 